\title{
CRÍTICA PÓS-MODERNA AO PARADIGMA EPISTEMOLÓGICO DA MODERNIDADE E SUAS IMPLICAÇÕES NA EDUCAÇÃO: CONTRIBUIÇÕES DA INTERDISCIPLINARIDADE
}

\author{
João Paulo Rodrigues ${ }^{1}$ \\ Claudiney José de Sousa ${ }^{2}$
}

\begin{abstract}
Resumo:
O objetivo deste artigo é analisar os paradigmas epistemológicos da modernidade e da pós-modernidade e suas influências na educação, apresentando algumas contribuições da interdisciplinaridade como alternativa para o desenvolvimento de uma educação emancipatória. Trata-se de uma pesquisa bibliográfica, utilizando-se o método dialético. A modernidade apresentou como foco principal a emancipação humana, através da confiança na racionalidade científica, o que desencadeou uma fragmentação do conhecimento. Porém, os pós-modernos acreditam que o projeto da modernidade não se concretizou, pois não é possível compreender a complexa realidade através da divisão das disciplinas, proposta pelos modernos. Feyerabend fala acerca de um "tratamento médico para a epistemologia" e Japiassu se refere ao problema em termos de "patologia do saber". Ambas as expressões metafóricas indicam o sintoma de algo preocupante na saúde da epistemologia atual e a necessidade de seu tratamento. O presente artigo desenvolve uma reflexão acerca da ideia de que o projeto emancipatório da modernidade ainda poderia ser alcançado, caso ocorra na educação a alteração do paradigma epistemológico da disciplinaridade pelo paradigma epistemológico da interdisciplinaridade. O ensino interdisciplinar deve ser desenvolvido com vivência, convívio, experimentação e cultivo, por isso a atitude interdisciplinar deve ser promovida através da criação de situações-problemas pensadas e elaboradas para serem resolvidas de modo interdisciplinar.
\end{abstract}

Palavras-chave: Modernidade. Pós-modernidade. Epistemologia. Educação. Interdisciplinaridade.

\section{POST-MODERN CRITICISM TO THE MODERNITY EPISTEMOLOGICAL PARADIGM AND ITS IMPLICATIONS IN EDUCATION: INTERDISCIPLINARITY CONTRIBUTIONS}

\begin{abstract}
:
This article aims to analyze the epistemological paradigms of modernity and postmodernity and their influences on education, presenting some contributions of interdisciplinarity as an alternative for the development of an emancipatory education. This is a bibliographical research on which was used the dialectic method. Modernity brought the human emancipation up as the main focus, through trust in scientific rationality, which unleashed a knowledge fragmentation. However, Postmodernists believe that the modernity project has not materialized, because it is not possible to understand the complex reality through the subjects division suggested by moderns. Feyerabend concerns about "medical treatment for the epistemology" and Japiassu refers to the problem in terms of "pathology of knowledge". Both metaphorical expressions indicate the symptom of something unsettling to the current epistemology healthy and the necessity for its treatment. This article develops a reflection on the idea that the modernity emancipatory project could still be achieved, if education changes the disciplinarity epistemological paradigm by the interdisciplinarity epistemological paradigm. The interdisciplinary teaching must be developed with life experience, conviviality, experimentation and cultivation, that's why the interdisciplinary attitude must be developed through the creation of problem situations thought and elaborated to be solved in an interdisciplinary way.
\end{abstract}

Keywords: Modernity. Postmodernity. Epistemology. Education. Interdisciplinarity.

1 Mestre em Filosofia pelo Programa de Pós-Graduação em Filosofia da Universidade Estadual de Londrina (UEL) (Londrina, 2014-2015). Professor de Filosofia no Ensino Médio pela SEED-PR. Integrante do Grupo de Pesquisa "Filosofia, educação e condição humana". E-mail: j.p_rodrigues @ hotmail.com

2 Doutor em Filosofia pelo Programa de Pós-Graduação em Filosofia da Unicamp (UNICAMP). Professor Adjunto do Departamento de Filosofia da Universidade Estadual de Londrina (UEL). E-mail: claudineyuel@hotmail.com 


\section{Introdução}

Ao confiar na racionalidade científica como único modo de se alcançar o conhecimento, a modernidade desenvolveu o fortalecimento de uma epistemologia fundamentada em uma lógica disciplinar fragmentada. A pós-modernidade, por sua vez, apresenta a ideia de que o ideal emancipatório da modernidade se frustrou, tendo em vista que o mundo contemporâneo apresenta uma lógica complexa e que, portanto, devemos desenvolver a construção de uma epistemologia complexa. Sabendo que as dificuldades e as incertezas presentes no contexto educacional contemporâneo estão relacionadas com o debate entre modernidade e pós-modernidade, este estudo apresenta a hipótese de que o projeto emancipatório da modernidade não se esgotou por completo, na verdade, devemos aprender com os erros da modernidade, ao entender que não conseguiremos almejar a emancipação proposta pelo projeto moderno caso não compreendamos a complexidade do conhecimento, portanto, devemos alterar o paradigma epistemológico da fragmentação do conhecimento pelo paradigma epistemológico da interdisciplinaridade.

Para desenvolver as ideias aqui abordadas, o artigo irá se nortear pelos seguintes problemas: como são caracterizados os paradigmas epistemológicos dos períodos históricos da modernidade e pós-modernidade? Como a educação se desenvolveu nos períodos moderno e pós-moderno? De que modo a interdisciplinaridade apresenta-se como caminho para a superação da atual crise educacional? Em que sentido a interdisciplinaridade pode trazer ao estudante contemporâneo a possibilidade de emancipação cognitiva, social e política?

\subsection{O conhecimento fragmentado produzido pela modernidade e a crítica pós-moderna}

No período histórico da modernidade o ser humano toma consciência de suas capacidades racionais, para assim descobrir os segredos da natureza. Ao confiar na racionalidade científica como único modo de alcançar o conhecimento, a modernidade apostou suas fichas na ideia de progresso secular, trazendo assim a capacidade de emancipação humana sem a necessidade de se apoiar na expectativa salvacionista externa, apresentada pela Igreja no período medieval ${ }^{3}$. Porém, se na Idade Média a ideia de salvação ocorria por meio da fé, na

3 "O mito para o homem pré-histórico, a ideia de cosmos no mundo grego e a aceitação de um Deus criador e protetor do cosmos na Idade Média sempre sustentaram a unidade do saber e garantiram a integridade do horizonte epistemológico. A mentalidade arcaica foi definitivamente superada pelo racionalismo grego. A razão é uma invenção helênica. [...] Contudo, tanto o saber antigo quanto o saber medieval inscrevem-se no horizonte epistemológico do cosmos. [...] Permanece, [...] na Idade Média, a mesma visão unitária do real. Permanece o mesmo horizonte epistemológico. As 'ciências' continuam vinculadas à filosofia. O sábio é ao

\begin{tabular}{l|l|l|l|l|} 
Qooista Dialectus & Ano 10 & n. 22 & Edição Especial, junho 2021 & p. 98 - 115 \\
\hline
\end{tabular}


modernidade a salvação se dava através da racionalidade, em um sentido de "emancipação", considerando então a participação ativa do ser humano e a não necessidade mais de uma assistência divina. A atividade racional assentada no mundo físico e social toma o lugar da contemplação e passividade medieval (GOERGEN, 2012, p. 152-153).

\begin{abstract}
Ao tornar-se o preceito fundamental da modernidade, a subjetividade produz uma profunda reviravolta epistemológica. De especulativo e pouco relacionado com as questões práticas da vida, o conhecimento passa a congregar [...] as formas de conhecer e de se relacionar com a natureza. O conhecer plenifica seu sentido na transformação e no domínio. Este movimento epistemológico representa o giro paradigmático que secularizou as expectativas emancipatórias do ser humano. (GOERGEN, 2012, p. 153).
\end{abstract}

Segundo Gallo (2006, p. 556), a pretensão da modernidade era de construir um método universal para a produção do conhecimento. Portanto, há o fortalecimento da lógica disciplinar fragmentada, que desenvolve um modelo de produção dos saberes e uma lógica da pesquisa, tendo por intuito o alcance de um conhecimento objetivo e universal, reconhecendo assim sua validade e veracidade. Tal entendimento marcará uma profunda influência não só na filosofia e ciência, mas também na educação.

De acordo com Santos (2008, p. 73-74), a ciência moderna é a precursora do conhecimento especializado. Na medida em que o conhecimento se torna mais restrito, mais 100 rigoroso ele se torna. Por ser um conhecimento disciplinar, passa a ser também disciplinado, pois, além de se especializar em diversos campos do saber científico, também policia as fronteiras entre as disciplinas e coíbe as disciplinas que tentam ultrapassar tais limites.

Sabe-se que a especialização do conhecimento e o seu consequente reducionismo arbitrário produziram males no decorrer do tempo. Porém, a tentativa de desenvolver medidas para corrigir tais erros acabou desenvolvendo mais especializações, através da criação de novas disciplinas, que apesar de terem o objetivo de resolverem os problemas criados pelas antigas disciplinas, de fato apenas reiterou a mesma espécie de cientificidade (SANTOS, 2008, p. 7576).

A especialização exagerada e sem limites das disciplinas científicas, a partir sobretudo do século XIX, culmina cada vez mais numa fragmentação crescente do horizonte epistemológico. No final de contas, para retomarmos a célebre expressão de G. K. Chesterton, o especialista converteu-se neste homem que, à força de conhecer cada vez mais sobre um objeto cada vez menos extenso, acaba por saber tudo sobre o nada (JAPIASSU, 1976, p. 40-41).

mesmo tempo um pensador, um filósofo e um teólogo. Sua função é colocar ordem nas coisas, pois a sabedoria é a perfeição suprema da razão. E é próprio da razão conhecer a ordem. [...] Tanto o cosmos grego quanto o medieval protegiam o homem, afastavam-no do desespero e da angústia, situavam-no existencial e metafisicamente em seu lugar dentro do cosmos. O saber só podia exercer-se no âmbito da totalidade. O conhecimento do particular só tinha sentido na medida em que remetia ao todo. A esse esquema epistemológico global corresponde uma pedagogia unitária" (JAPIASSU, 1976, p. 45-46).

\begin{tabular}{|l|l|l|l|l|}
\hline Qovista 2 ilalectus & Ano 10 & n. 22 & Edição Especial, junho 2021 & p. $98-115$ \\
\hline
\end{tabular}


Para os pós-modernos, a confiança que a modernidade relegou à razão como instrumento de emancipação humana foi frustrada. Nietzsche, Heidegger, Horkheimer, Adorno, Foucault e Lyotard apresentam a ideia de que a racionalidade moderna é a vilã dos eventos desastrosos que ocorreram nos últimos tempos, razão esta que inclusive mostra-se impotente, inoperante e cúmplice diante dos problemas causados pelos avanços científico-tecnológicos. A emancipação humana proposta pela modernidade não se concretizou, tendo em vista que o mundo contemporâneo apresenta um cenário cheio de guerras, de destruição ambiental, de fome e miséria, submetendo o ser humano à lógica técnico-científica e à organização econômica e jurídico-institucional da modernidade (GOERGEN, 2012, p. 154-155).

Conforme esclarece Goergen (2012, p. 159-161), enquanto os pós-modernos, entre eles Lyotard, defendem a falência da modernidade, outros ainda apresentam um projeto da modernidade que ainda pode ser alcançado caso seus desvios sejam corrigidos, por exemplo, Habermas. Porém, o que deve ser entendido no debate modernidade e pós-modernidade é que, de um lado, não podemos declarar tão apressadamente o fim da racionalidade moderna, tendo em vista os avanços científicos ocorridos durante o período moderno, e, por outro lado, não podemos ignorar as transformações e problemas que essa mesma racionalidade trouxe para a 101 humanidade. Portanto, devemos nos perguntar acerca da relação entre modernidade, pósmodernidade e educação, não somente desenvolvendo a questão de como educar o ser humano em nossos tempos, mas também buscar compreender o conceito de conhecimento na atualidade marcada por profundas transformações.

\subsection{A crise epistêmica da educação}

De acordo com Goergen (2012, p. 161-162), vivemos atualmente uma crise epistêmica, pois se o conceito de conhecimento estava antes atrelado ao conceito de verdade, com o surgimento da racionalidade instrumental, a verdade passou a ser ligada aos conceitos de poder, domínio e utilidade, afinal, Horkheimer e Adorno, e antes deles Weber, entenderam que a razão instrumental tem a capacidade de criar resultados concretos, através da técnica apta a dominar e intervir na natureza. Ao ligar o conceito de conhecimento à razão instrumental, o sentido da educação começa a sofrer também uma profunda ressignificação, colocando a educação contemporânea em crise. Sabendo que no projeto da modernidade o conhecimento tinha a função de proporcionar a emancipação humana, questiona-se atualmente acerca do que ocorre com esse ideal quando a educação começa a se fundar com base na razão instrumental. 
Ao tomar para si um caráter universal e objetivo, a racionalidade moderna torna-se também um modelo totalitário, pois recusa o caráter racional de todos os outros tipos de conhecimento que estejam fundamentados em seus próprios princípios epistemológicos e em suas próprias regras metodológicas, ao determinar a racionalidade científica como a única forma de conhecimento verdadeiro (SANTOS, 2008, p. 21-22). Nos moldes da ciência moderna, conhecer é quantificar, portanto, se o rigor científico ocorre por meio das medições, o que não se pode quantificar não é relevante para a ciência. Além disso, o método científico fundamenta-se na redução da complexidade, já que, se o ser humano não pode compreender completamente o complexo mundo, deve-se então dividir e classificar para, posteriormente, estabelecer as relações sistemáticas entre aquilo que se dividiu e classificou, como bem aponta Descartes nas suas Regras do Método (SANTOS, 2008, p. 27-28).

Conforme Santos (2008, p. 18-19), vivemos em um tempo complexo, em uma fase de transição. Necessitamos questionar acerca das relações entre a ciência e a virtude, além de questionar também sobre o sentido do conhecimento científico acumulado tanto para o enriquecimento quanto para o empobrecimento prático das nossas vidas. No entanto, as respostas para essas questões estão longe de serem simples. Se o ciclo da supremacia da ordem 102 científica moderna está chegando ao fim, precisaremos buscar novas respostas para compreender o tempo na qual vivemos, para além das respostas que a modernidade outrora nos apresentaram.

Segundo Goergen (2012, p. 162-163), a pós-modernidade questiona os próprios fundamentos da legitimação da modernidade, esta que possui a pretensão de dominar racionalmente a fundamentação do social, como projeto emancipatório. Porém, para legitimar um projeto educativo neste contexto, torna-se necessário refletir acerca do argumento pósmoderno, a saber, a ideia de que devemos abandonar o projeto moderno tendo em vista a constante transformação atual, pois devemos levar em consideração as consequências desse argumento no campo da educação, já que, se de um lado, o argumento pós-moderno representa a libertação da racionalidade moderna universalizante, de outro lado, pode representar também a submissão da humanidade à razão instrumental.

De acordo com Goergen (2012, p. 166-167), a educação contemporânea está em crise pois a prática educativa está perdendo o seu principal pilar, a saber, a confiança na racionalidade moderna. Atualmente, são abandonadas as metanarrativas, as tradições epistemológicas e a ideia de uma história em progresso permanente. A pós-modernidade traz à luz uma realidade em constante transformação, o que deve ser assumido de forma crítica pela 
educação. Porém, não devemos defender cegamente a modernidade e nem adotar fielmente a pós-modernidade, mas sim debater acerca das duas posições para assim desenvolver direcionamentos que nos orientem para a idealização de uma educação que esteja de acordo com a realidade contemporânea.

Deve-se destacar que o mais importante é saber se a educação está objetivando a manutenção da realidade ou a sua transformação. Por isso, deve-se analisar os aspectos epistemológicos da modernidade e da pós-modernidade, para assim aprender os possíveis caminhos e possibilidades que se descortinam para um conhecimento articulado ao redor de um projeto educacional evidentemente emancipatório (GALLO, 2006, p. 564).

Segundo Henrique (2005, p. 13-14), a sociedade do século XXI está passando por mudanças amplas, profundas e rápidas de modo ímpar na história. A globalização, os problemas do meio ambiente, as questões éticas se tornando mais complexas a cada dia, conflito entre novas normas e comportamentos culturais com os valores tradicionais e as relações cada vez mais complexas entre a sociedade, os indivíduos e as instituições se apresentam como alguns dos desafios de nossa época. Sendo assim, faz-se necessário cogitar a ideia de uma educação cada vez mais eminente e continuamente renovada, com o objetivo de desenvolver um cidadão emancipado que possua as capacidades necessárias para enfrentar melhor os novos desafios de nosso tempo.

\footnotetext{
Estamos, pois, em uma época de crise e de problemas novos. Temos o sentimento acentuado de uma insuficiência dos velhos métodos científicos baseados na compartimentalização, na fragmentação, na redução ao simples e ao lógicomatemático. Temos o sentimento de que algo envelheceu nos métodos que conheceram o sucesso, mas que hoje não podem mais responder ao desafio global da complexidade (HENRIQUE, 2005, p. 14).
}

Porém, não se pretende, com isso, uma negação de todo o avanço científico que ocorreu até hoje, mas sim a pretensão de que é necessário desenvolver um conhecimento científico que religue, contextualize e globalize os saberes que ainda são trabalhados de forma fragmentada e compartimentada, realizando assim uma articulação entre as disciplinas (HENRIQUE, 2005, p. 14).

Conforme Sousa et al. (2017, p. 94), o meio educacional se estabeleceu sob o prisma do paradigma da modernidade, caracterizando assim um modelo pedagógico que tem como fundamental aspecto a compartimentalização, a fragmentação do conhecimento e uma racionalidade excludente, marginalizando o sujeito em sua multidimensionalidade e em sua diversidade de saberes existentes no contexto vivencial. Neste sentido, o surgimento de epistemologias que compreendem o mundo por meio de uma lógica complexa nos traz o 
questionamento da visão do paradigma da modernidade, percebendo a verificação do seu esgotamento para as explicações do mundo contemporâneo, tendo em vista suas mutações constantes. Assim, há a necessidade de se repensar a ação pedagógica, orientando-os segundo uma perspectiva sistêmica e interdisciplinar e transdisciplinar, alterando a compartimentalização por integração. Desse modo, a metodologia interdisciplinar e a transdisciplinar apresentam a possibilidade de saída de uma visão mecanicista e reprodutiva para que possam ser pensadas como uma construção complexa de conhecimento. Assim, podese perceber "que as reflexões da prática pedagógica referenciada nos fundamentos epistemometodológicos da transdisciplinaridade propõem o questionamento e o redirecionamento da cultura educacional que se comporta pelo olhar da fragmentação" (SOUSA et al., 2017, p. 102).

\footnotetext{
No que diz respeito à ação pedagógica, algumas características podem ser pontuadas, dentre as quais: mudança na relação hierárquica entre professor e estudante, pautando essa relação no diálogo e na escuta sensível; relativização na lógica de transferência do conhecimento - o estudante com suas construções prévias é visto como agente de sua aprendizagem; aula como elemento construído conjuntamente - professor e estudantes; inserção e valorização de saberes que estão para além dos conhecimentos acadêmicos; promoção de um conhecimento contextualizado com a realidade local; estratégias didáticas que permitam a participação ativa dos discentes. Assim sendo, a partir das considerações tecidas, cabe ressaltar que o desenvolvimento da ação pedagógica, tendo por alicerce a interdisciplinaridade e a transdisciplinaridade, se sustenta em um movimento de atitude frente à constatação da insuficiência dos modelos que têm configurado o contexto educacional e das exigências da contemporaneidade, que requerem uma visão ampliada sobre os processos que envolvem as múltiplas dimensões da vida humana (SOUSA et al., 2017, p. 108).
}

A crise na educação contemporânea pode ser fruto do debate epistemológico entre modernidade e pós-modernidade. Porém, não devemos abandonar apressadamente o projeto moderno e nem abraçar passivamente as conclusões da pós-modernidade, mas sim perceber que o objetivo emancipatório da modernidade é válido, mas vai pelo caminho errado, qual seja, o caminho da fragmentação do conhecimento, trazendo como consequência a não compreensão completa da realidade, esta que se mostra complexa. Sendo assim, ainda é possível resgatar o projeto emancipatório da modernidade, desde que a educação realize uma revolução em seu paradigma epistemológico, a saber, do paradigma disciplinar para o paradigma interdisciplinar.

\subsection{A "patologia do saber" e a interdisciplinaridade como tratamento médico para as doenças da epistemologia disciplinar}

Pretendemos mostrar alguns aspectos de como se construir uma epistemologia interdisciplinar ${ }^{4}$, no sentido de lançar algumas luzes sobre o modelo epistemológico que

4 "[O interdisciplinar] pode ser caracterizado como o nível em que a colaboração entre as diversas disciplinas ou entre os setores heterogêneos de uma mesma ciência conduz a integrações propriamente ditas, isto é, a uma certa

\begin{tabular}{|l|l|l|l|l|l|}
\hline Qovista & Oilalectus & Ano 10 & n. 22 & Edição Especial, junho 2021 & p. $98-115$ \\
\hline
\end{tabular}


necessitamos para a educação do presente e do futuro. Nesse sentido, apresentamos algumas facetas dessa fragmentação no processo de construção do conhecimento disciplinar. Embora tomemos a ciência como forma exemplar dessa fragmentação, entendemos que esta crítica pode ser estendida também a outros âmbitos do saber como filosofia, teologia, arte, política, tecnologia e até mesmo senso comum.

Iniciaremos esta discussão a partir de uma passagem bastante polêmica da obra Contra o método, em que o filósofo austríaco Paul Feyerabend (1924-1994) fala da história da ciência como uma grande aventura de construção do conhecimento.

\begin{abstract}
A história da ciência, bem vistas as coisas, não consiste apenas em fatos e em conclusões extraídas dos fatos. Contem também ideias, interpretações dos fatos, problemas criados por interpretações conflituais, erros, e assim por diante. Numa análise mais fina descobrimos até que a ciência não conhece "fatos nus", mas que os fatos que entram no nosso conhecimento são já vistos de certa maneira e, por isso, essencialmente ideacionais. Sendo assim, a história da ciência seria tão complexa, caótica, cheia de erros e divertida com as ideias que contem, e estas ideias seriam, por sua vez, tão complexas, caóticas, cheias de erros e divertidas como os espíritos dos que as inventaram (FEYERABEND, 1993, p. 25).
\end{abstract}

O filósofo critica o fato de a epistemologia, a história da ciência e a educação atual promoverem o que ele chama de uma "lavagem cerebral", que deturpa estes acontecimentos, colocando em seu lugar um relato enfadonho, simples, uniforme, objetivo e cheio de regras. A 105 educação científica hegemônica oculta a "real" história da ciência.

Feyerabend revolucionou a epistemologia ao adotar uma nova perspectiva na análise do saber científico e de sua historiografia. Podemos falar de um novo e instigante paradigma epistemológico segundo o qual o conhecimento é concebido como algo muito mais rico, complexo, divertido e atraente do que o melhor cientista ou epistemólogo poderia imaginar ou possa tentar descrever. Então, o que dizer das magras descrições do conhecimento científico às quais temos acesso na educação escolar?

O filósofo inicia sua obra Contra o Método falando da necessidade de um "tratamento médico para a epistemologia" (FEYERABEND, 1993, p. 23). Na mesma esteira dessa discussão, Hilton Japiassu se refere ao problema em termos de uma "patologia do saber" (1976). Estas expressões metafóricas são um sintoma de que algo muito preocupante está

reciprocidade nos intercâmbios, de tal forma que, no final do processo interativo, cada disciplina saia enriquecida. Podemos dizer que nos reconhecemos diante de um empreendimento interdisciplinar todas as vezes em que ele conseguir incorporar os resultados de várias especialidades, que tomar de empréstimo a outras disciplinas certos instrumentos e técnicas metodológicos, fazendo uso dos esquemas conceituais e das análises que se encontram nos diversos ramos do saber, a fim de fazê-los integrarem e convergirem, depois de terem sido comparados e julgados. Donde podemos dizer que o papel específico da atividade interdisciplinar consiste, primordialmente, em lançar uma ponte para religar as fronteiras que haviam sido estabelecidas anteriormente entre as disciplinas com o objetivo preciso de assegurar a cada uma seu caráter propriamente positivo, segundo modos particulares e com resultados específicos" (JAPIASSU, 1976, p. 75). 
ocorrendo na saúde da epistemologia atual. Um sintoma que coloca a necessidade de tratamento imediato. Veremos, nas discussões a seguir, que felizmente não estamos a falar de uma doença terminal, da necessidade de amputação de membros ou outras medidas extremas. Perceberemos que o restabelecimento da saúde da epistemologia depende muito mais de pequenos atos compartilhados, de uma série de medidas de higiene conceitual, teórica, metodológica e de alguns tratamentos alternativos.

Para avançar na discussão desta complexa temática optamos por também lançar mão de algumas metáforas que nos ajudarão na compreensão dos argumentos e nos colocarão no cenário da atitude interdisciplinar que abordaremos a seguir.

Imaginemos que um grupo de arqueólogos, em busca de um fóssil muito raro, empreenda uma longa viagem para uma região remota de um país distante. O grupo faz alto investimento em equipamentos de trabalho e de segurança; enfrenta mudanças climáticas severas; vive a solidão dos vários meses distante da família e de outras pessoas queridas; aprende com as alegrias e tristezas, desilusões, erros e acertos de cada escavação. Todos os integrantes sabem que não há nenhuma garantia de que o objeto que investigam possa ser realmente localizado. Somente eles são testemunhas do intenso aprendizado que esta aventura 106 lhes proporciona. Depois do longo e intenso período de trabalhos e estudos, do investimento, desgaste físico e emocional, absolutamente nada é encontrado. Compreendem a importância da expedição, mas sabem que, infelizmente, este evento está destinado a ser uma página esquecida na história da ciência.

Suponhamos agora que meses depois, após terem avaliado cuidadosamente erros e acertos da expedição anterior, o mesmo grupo de arqueólogos empreenda uma segunda investigação - agora em local diferente. Vivem as mesmas intempéries, as mesmas dificuldades, o desgaste, a solidão, o risco de contrair doenças e de nada encontrar. Imaginemos, porém, que desta vez tenham sido bem sucedidos. Muitos erros cometidos no evento anterior serviram de aprendizado para esta nova empreitada. Logo nos primeiros dias de escavações localizam o tão esperado fóssil de milhares de anos. O material é exposto num museu de ciências naturais de uma respeitada universidade. Os pesquisadores publicam artigos em conceituadas revistas científicas e são convidados para muitas palestras e entrevistas. O fóssil encontrado abre caminho para a compreensão de uma série de fenômenos relacionados a outras áreas de conhecimento: biologia, geografia, antropologia, história, química, física, paleontologia, geologia, etc. 
Qual a "real" história por trás da descoberta do fóssil? Quem, de fato, está autorizado a contar esta história? Existe uma separação entre os dois eventos contados acima? Por que o primeiro evento, apesar de todo aprendizado que proporcionou, não tem espaço privilegiado na história da ciência? Quem estabelece os critérios do que pode ou não ser publicado sobre as duas importantes expedições descritas acima?

Se pudéssemos convidar os referidos pesquisadores para uma entrevista sobre o ocorrido é bem provável que, em suas falas, revelariam que a aventura vivenciada nas duas expedições tem, para eles, um significado bem maior do que a exposição no museu e a descrição objetiva sobre o fóssil na revista científica. Segundo Feyerabend isso ocorre porque "a ciência não conhece fatos nus (...) os fatos que entram no nosso conhecimento são já vistos de certa maneira e, por isso, essencialmente ideacionais" (1993, p. 25). O material recolhido na escavação é apenas a representação visual e tátil da fantástica aventura do conhecimento vivenciada por aqueles indivíduos. O objeto, agora exposto no museu, e o texto na revista científica, deveriam falar também das decepções da busca, dos riscos, das alegrias e tristezas da expedição. Mas se mostram diante de nós como produtos acabados, como objetos rígidos, fechados, definitivos, mudos, independentes das subjetividades a eles atreladas.

Com base nisso nos perguntamos: o que é, então, a ciência? É o produto, o conceito, a descrição teórica, a demonstração lógica? O que mais entra em nossa definição de conhecimento científico?

Se visitarmos hoje o American Museum of Natural History nos Estados Unidos, fundado em 1869, um dos maiores e mais importantes museus do mundo, veremos uma vasta coleção com mais de 30 milhões de fósseis. Para a ciência disciplinar, cada um deles é uma espécie de troféu de uma escavação bem sucedida. Mas aos olhos atentos da epistemologia interdisciplinar revelam uma rica história de erros e acertos, tentativas frustradas, sonhos, perdas, enganos, desilusões, mentiras, mortes, fraudes e conquistas dos pesquisadores. Além disso, cada fóssil fala sobre a importância de outras formas de vida e pode servir como elemento para avaliação da postura arrogante e predatória da vida humana sobre a Terra - hegemônica, dominante, prepotente. Infelizmente a epistemologia e a historiografia tradicionais da ciência insistem em mostrar que não há museu que comporte tanta subjetividade. Tudo isso seria demasiadamente humano para estar no rol da ciência séria, objetiva, racional. Por que levar em consideração essas idiossincrasias?

Vejamos outro exemplo: um dos maiores acontecimentos no campo da genética molecular dos últimos anos foi apresentada em apenas uma página do volume 171 da revista

\begin{tabular}{|c|c|c|c|c|}
\hline Qovista Dialectus & Ano 10 & n. 22 & Edicão Esnecial iunho 2021 & p. $98-115$ \\
\hline
\end{tabular}


Nature, em 1953. James Dewey Watson e Francis Harry Compton Crick descrevem ali a estrutura molecular dos ácidos nucleicos. Como é possível que um fenômeno desta magnitude possa ser descrito em apenas uma página? Ao analisar o artigo nos surpreendemos com o fato de que praticamente nada daquilo que epistemólogos chamam de contexto de descoberta é mencionado no artigo. A rígida descrição da estrutura do DNA, no artigo de 1953, é apenas a magra justificação do complexo processo de construção daquele saber.

O discurso científico hegemônico e disciplinar diz que temos nesta magra descrição a prova cabal e lógica, o atestado, o relato da comprovação, a exposição dos princípios, o troféu dos descobridores. $\mathrm{O}$ artigo seria o atestado de que a estrutura é logicamente coerente com os princípios da química. Mas, na verdade, sabemos que o texto revela, antes de tudo, as características de um ritual quase religioso. Um rito que legitima um mito - o mito da "verdadeira história da descoberta do DNA". O mito da racionalidade científica, que esconde os jogos de poder. Conforme afirma Feyerabend (1993, p. 14), "a ciência ocidental reina hoje em termos soberanos sobre todo o globo; contudo, a razão desse fato não está na compreensão de sua "racionalidade imanente, mas nos jogos de poder". Tudo isso só legitima ainda mais a contradição na qual esse tipo de ciência hegemônica disciplinar incorre. Difunde o princípio da 108 objetividade enquanto está ancorada em princípios subjetivos - talvez o mais influente deles exatamente a sede de poder.

Sabemos que, por trás da "história oficial da descoberta do DNA" corre uma história clandestina, uma história marginal, muito mais instigante e interessante, que mostra o caráter interdisciplinar e transdisciplinar do processo de construção do saber sobre os ácidos nucleicos, que obviamente não teve início com Watson e Crick e que, felizmente, não terminou com eles. Por que, então, demarcar apenas este momento com um ritual, um troféu, um atestado, uma celebração? Entendemos a importância da pesquisa destes teóricos e julgamos absolutamente pertinente a descrição, o registro, a celebração das descobertas, invenções, criações ou qualquer outro nome que queiramos dar às novidades da ciência. O que se questiona é apenas a maneira como se tem registrado e transmitido o que ocorre. $\mathrm{O}$ fato de servirem antes para instaurar uma hierarquia e promover uma cisão entre sábios e ignorantes, dominadores e dominados, capazes e incapazes.

Temos o péssimo hábito de atribuir as soluções aos experts, aos especialistas nas mais diferentes esferas da vida humana: ciência, política, religião, economia, moral, tecnologia etc. Para Gusdorf, essa confiança exagerada em soluções individuais e heroicas tem nos decepcionado em muitas ocasiões. 


\begin{abstract}
Depositamos nossa confiança nos experts, muito embora nossa confiança neles mil vezes tenha sido decepcionada. Os experts são os homens do provisório, aos quais é confiada a responsabilidade de assegurarem à humanidade uma precária sobrevivência. Especialista nesta ou naquela questão precisa, nos domínios político, científico, econômico ou social, o expert é suposto saber o que os outros não sabem. A seus olhos, todo problema deve ter uma solução, desde que sejam tomadas as medidas adequadas (GUSDORF, 1976, p. 8).
\end{abstract}

Atribuímos um alto valor à ciência disciplinar, das publicações, dos textos didáticos, aquela ensinada em sala de aula. E quanto à ciência processo, realizada no laboratório, feita de intrigas, sonhos, expectativas, feita mais de erros do que de acertos, mais de incertezas do que de certezas? A interação entre ciência-disciplina e ciência-processo, para utilizar as expressões de Freire-Maia $(2000,2008)$ é o que nos permite fazer a experiência da interdisciplinaridade. Não faz sentido ensinar a partir de um conjunto estanque do saber - seja ele a disciplina ou o processo, seja ele o contexto de justificação ou o contexto de descoberta, conforme afirma Reichenbach (1976). Disciplina e processo, justificação e descoberta, vistos em conjunto, nos dão a totalidade e a complexidade do saber científico.

A esse respeito diz Feyerabend (1993, p. 12),

os êxitos científicos não podem ser explicados de maneira simples. Não podemos dizer: "A estrutura do núcleo do átomo foi descoberta porque as pessoas fizeram A, B, C..." Sendo A, B, C operações ou procedimentos suscetíveis de serem entendidos independentemente do seu uso na física nuclear. Tudo o que podemos fazer é dar conta em termos históricos dos passos concretos, incluindo-se nestes as circunstâncias sociais e idiossincrasias dos indivíduos.

Para a concepção neopositivista e disciplinar de ciência, assim como para o cinema sensacionalista, não é nada atraente ter que admitir que a história é uma construção conjunta de homens e mulheres comuns. Difícil admitir que não existam super-heróis ou super-heroínas. No cinema pode ser atraente, divertido, estimulante e até catártico ver que alguns poucos poderosos resolvem os problemas da humanidade. Mas na vida real, sobretudo na educação, esta atitude é catastrófica. Que benefício poderia ter a consideração de que existem alguns poucos gênios, sábios, gurus, descobridores, grandes teóricos na ciência, na filosofia, na política, na educação?

Temos aqui mais um dos aspectos da patologia cisão/fragmentação do saber: a distinção entre homens/mulheres comuns e os heróis ou heroínas, entre os ignorantes e os sábios. A história que nos contam é a de que Rosalind Franklin, Linus Pauling, Robert B. Corey e Maurice Wilkins foram cientistas exemplares, importantes para a decifração da estrutura do DNA, mas não considerados "geniais" como Watson e Crick. Assim são inventadas as hierarquias, construídos títulos, distribuídas as medalhas. Nesse jogo, cabe aos "ignorantes", 
súditos, leigos, assistir boquiabertos aos "grandes acontecimentos", aplaudir, prestar culto e homenagem aos vencedores, grandes homens e mulheres.

O que é hoje o ensino de ciência nas escolas senão uma forma de celebrar, ritualizar, cultuar estes supostos deuses? O que são as grandes universidades e institutos de pesquisas senão templos do saber? Prevalece a ideia de um saber posse, propriedade. Por que falamos do mal de Alzheimer, o mal de Parkinson, o grau Celsius, o princípio de Arquimedes, a constante de Planck, o modelo atômico de Bohr, a equação de Schorodinger, as leis de Newton, as leis de Mendel, o plano cartesiano, o teorema de Pitágoras? Sabemos que é mais do que uma questão didática. É uma questão de "saber propriedade", que demarca a "fronteira entre as disciplinas", que estabelece de quem é a posse de cada uma destas descobertas.

Ora, a ciência que se ensina e que se faz é um produto social como outro qualquer. Sua organização e seus membros se submetem aos mesmos parâmetros sociais. Há nela dominação, exploração, prostituição, neuroses, estratificações, mentiras, ódios etc. Os cientistas também formam um grupo de interesses. A neurose começa quando apresentam aos outros, na ação pedagógica, a imagem falsa da segurança, de detentores exclusivos de um saber racional e objetivo, de arautos da verdade (JAPIASSU, 2011, p. 32).

\subsection{A atitude interdisciplinar: espera vigiada e equilíbrio}

Talvez, de todas as segmentações de que tratamos até aqui nenhuma seja tão prejudicial ao projeto de construção de um saber interdisciplinar quanto a distância entre educador e educando. Impossível pensar uma educação que supere realmente a disciplinaridade sem que supere antes essa dicotomia. De nada adiantaria a interdisciplinaridade ser uma realidade apenas para um dos polos da relação. Pesquisadores, educadores, professores podem estar convictos de que realizam um projeto de unificação do saber pelo simples fato de estarem de posse da crença de que compreendem perfeitamente o que significa este conceito, a interdisciplinaridade.

Caso o educando, o assistente, o estagiário, o filho não possam ou não consigam vivenciar na mesma intensidade essa experiência e essa crença, podemos dizer que esteja ocorrendo interdisciplinaridade na relação ensino/aprendizagem? Não corremos o risco de estarmos a viver (bem-intencionados inclusive) apenas para nós mesmos esta proposta? Como agir de forma que não seja apenas uma ilusão, um sonho, um devaneio, mas uma real experiência que se vive em conjunto, em parceria, em comunidade de investigação? Como saber, afinal, se estamos fazendo a experiência da interdisciplinaridade? Como saber se nossos estudantes não encaram nossa postura supostamente interdisciplinar como a postura de mais

\begin{tabular}{|c|c|c|c|c|}
\hline Qevista Dialectus & Ano 10 & n 22 & Edicão Fsnecial junho 2021 & n 98 \\
\hline
\end{tabular}


um a ministrar uma disciplina: a disciplina da interdisciplinaridade? Vemos, portanto, que a compreensão do caráter interdisciplinar do conhecimento, da realidade, das ideias, das teorias, dos fenômenos requer um aprendizado acerca da totalidade, da complexidade das coisas.

Ao fazer referência a esta dificuldade na concretização de um efetivo saber interdisciplinar, Fazenda (2011, p. 28) fala de uma atitude cuidadosa, curiosa, que é ao mesmo tempo paradoxal, contraditória e ambígua - experiência a qual todos os comprometidos com esta causa estão destinados a viver. A estes a autora recomenda uma atitude de paciência, serenidade e espera. Mas a autora alerta que esta não pode ser uma espera passiva, mas antes uma espera vigiada e prudente, que não se antecipa na tentativa de querer "alterar violentamente o curso dos fatos".

O cuidado primeiro que se deve ter é o de encontrar-se o ponto ótimo de equilíbrio no movimento engendrado por essa ambiguidade: da imobilidade ao caos. As fontes novas de saber vivenciadas no conhecimento interdisciplinar permitem-nos facilmente reconhecer que a estrutura na qual vivemos é reflexo de outras épocas, gestadas no passado. Sentimo-nos tolhidos, nesse processo, ao exercer o imperativo de ordens que não nos pertencem, a valores que não desejamos e nosso primeiro impulso é romper com ela. No entanto, o processo de metamorfose pelo qual passamos e que fatalmente nos conduzirá a um saber mais livre, mais nosso, mais próprio e mais feliz é um processo lento, exige uma atitude de espera. Não se trata, porém, de uma espera passiva, mas sim vigiada (FAZENDA, 2011, p. 27-28).

Fazenda (2011) nos fala de interdisciplinaridade enquanto atitude. Assim concebida, se aproxima de um comportamento ético e estético, uma tomada de decisão, algo que resulta de uma conversão. Significa deixar de seguir uma conduta para adotar outra. Certamente este é o ideal, a meta a ser continuamente conquistada. Mas talvez seja importante nos perguntamos a respeito de um motivador, um estímulo, um meio a engendrar este processo. Não podemos ignorar o fato de que no contexto em que vivemos exige-se meios viabilizadores. Utopias como a de Fazenda devem ser perseguidas, mantidas, almejadas. Mas a utopia não nos desautoriza de pensar em meios pragmáticos para a realização do sonho. Se queremos que uma criança tenha uma atitude respeitosa, então criamos mecanismos para atingir essa atitude, estabelecemos os meios para viabilizá-la. E quanto à atitude interdisciplinar? Não dá para ensinar metodicamente, formalmente a interdisciplinaridade sem incorrer no equívoco disciplinar.

Uma postura ética é desenvolvida com vivência, experiência, convívio, experimentação, hábito, cultivo. $\mathrm{O}$ mesmo vale para a atitude interdisciplinar. Aprendemos a interdisciplinaridade criando situações-problema que requeiram respostas interdisciplinares. De certa forma, criando situações propositalmente pensadas e elaboradas de forma que não possam ser resolvidas a não ser mediante a atitude interdisciplinar. Na verdade, estes problemas já

\begin{tabular}{|c|c|c|c|c|}
\hline Qevista Dialectus & Ano 10 & n. 22 & Edição Especial, junho 2021 & p. $98-115$ \\
\hline
\end{tabular}


existem. O que os educadores, com formação interdisciplinar, necessitariam seria apenas pensar estratégias conjuntas para que o objeto, o problema, o tema, a questão, a atividade, o exercício, a tarefa sejam enfrentados por várias disciplinas para serem executadas.

Como construir questões, problemas, temas interdisciplinares? Logo vemos que, ao colocar a questão, o que parecia ser apenas um problema rapidamente se transforma em solução, mostrando o caráter dialético do processo interdisciplinar. A busca converte-se, diante de nós, em um desafio interdisciplinar, que só encontrará uma solução "provisória" se for atacado/enfrentando também de forma interdisciplinar. Assim, um longo processo (longa cadeia) de elaboração, resolução de temas, problemas, objetos interdisciplinares ganha corpo e entra em "movimento perpétuo". Um processo dialético ininterrupto.

Educadores convocados a construir objetos interdisciplinares para que educandos resolvam, interpretem, analisem, reconstruam ou desconstruam, vivem intensamente a realidade destes mesmos problemas. Vivem uma interação que faz com que se desfaça, paulatinamente (com o desenvolvimento e amadurecimento do processo), a própria distinção entre quem concebe e quem executa a situação-problema. Temos provisoriamente uma distinção (concepção/execução) ainda característica do antigo paradigma, mas que é requerida 112 no que poderíamos chamar período pré-paradigmático da atitude interdisciplinar, que dará origem ao novo paradigma, cuja compreensão exige um insight, uma visão gestáltica, uma visão do todo - como descrita por Thomas Kuhn (2001), para fazer referência ao modo como ocorre a resolução de quebra-cabeças na ciência normal.

\section{Considerações finais}

Se comprarmos uma bicicleta que venha totalmente desmontada, só conseguiremos utilizá-la para dar um passeio se nos envolvermos no difícil trabalho de encaixar cada uma das peças corretamente. Os encaixes incorretos também se mostrarão importantíssimos no processo de aprendizagem. A partir desse exemplo é possível ver que devem ser valorizadas e preservadas também as disciplinas. A interdisciplinaridade é pensada com elas e a partir delas (como numa bicicleta com todas as suas peças - grandes e pequenas).

Tanto o ato de montar e desmontar uma bicicleta (em colaboração com outras pessoas: filhos, colegas, esposa, esposo, etc) como o ato de dialogar com profissionais de áreas diferentes de conhecimento é sempre um interessante aprendizado. Entre as pessoas envolvidas há um objeto interdisciplinar (a bicicleta que montamos juntos, a atividade teórica que estamos

\begin{tabular}{|c|c|c|c|c|}
\hline Q Rovista Dialeatus & Ano 10 & n. 22 & Edição Especial, junho 2021 & p. $98-115$ \\
\hline
\end{tabular}


tentando resolver, o filme que assistimos em grupo, etc) que faz a mediação não entre disciplinas, mas entre pessoas que compartilham um aprendizado. Trata-se antes de uma atitude, de um modo de vida, de um comportamento mais maduro, mais humano.

É possível ensinar a atitude interdisciplinar? Ela é composta de pequenos e grandes atos, fazeres, ideias, pensares, agires, comportamentos, saberes, etc. Podemos nos perguntar, a título de exemplo, o que é democracia? É possível ensinar democracia? Podemos falar de democracia, estudar a história da democracia, analisar o conceito, discutir a respeito, agir democraticamente ou antidemocraticamente. Assim, aprendemos democracia em sua práxis, em seu processo de ação/reflexão. Seria um absurdo dizer que alguém passou a agir democraticamente simplesmente porque fez um curso de democracia. O mesmo parece ocorrer com a atitude interdisciplinar. Nesse sentido, ela se identifica com uma espécie de ética, com a formação de um caráter. Falaríamos, assim, de conduta interdisciplinar. Parafraseando Michel Foucault (1985), a interdisciplinaridade, se concebida como uma ética e uma arte, possibilitaria a construção de uma estética da existência interdisciplinar.

Se assim for, a problemática em torno da epistemologia interdisciplinar nos conduz inevitavelmente a uma ética e a uma estética da existência. Novamente nos vemos envoltos pela 113 aura da interdisciplinaridade. Assim, alguma luz é lançada em toda essa discussão. O que é a interdisciplinaridade? Como agir interdisciplinarmente? Como viabilizar essa atitude? A resposta mais acertada parece ser: colocar o tema em questão é já plantar a semente do interdisciplinar. Se cair em terra fecunda e receber os devidos cuidados brotará e florescerá naturalmente no solo das relações humanas.

\section{REFERÊNCIAS}

FAZENDA, Ivani Catarina Arantes. Integração e interdisciplinaridade no ensino brasileiro. $6^{\mathrm{a}}$ ed. São Paulo: EDIÇÕES LOYOLA, 2011.

FEYERABEND, Paul. Contra o método. Trad. Miguel Serras Pereira. Lisboa: Relógio D’Água, 1993.

FOUCAUlT, Michel. História da Sexualidade, Vol. 3: O cuidado de si, Trad. de Maria Thereza C. Albuquerque. $8^{a}$ ed. Rio de Janeiro: Edições Graal, 1985.

FREIRE-MAIA, Newton. A ciência por dentro. Petrópolis: Vozes, 2000.

FREIRE-MAIA, Newton. Verdades da ciência e outras verdades: a visão de um cientista. São Paulo: Editora Unesp; Sociedade Brasileira de Genética, 2008.

\begin{tabular}{|l|l|l|l|l|}
\hline Qovista 2 ilalectus & Ano 10 & n. 22 & Edição Especial, junho 2021 & p. 98 - 115 \\
\hline
\end{tabular}


GALLO, Sílvio. Modernidade/pós-modernidade: tensões e repercussões na produção de conhecimento em educação. In: Educação e Pesquisa, São Paulo, v.32, n.3, p. 551-565, set./dez. $2006 . \quad$ Disponível em: https://www.scielo.br/scielo.php?script=sci_arttext\&pid=S1517-97022006000300009. Acesso em: jan. 2021.

GOERGEN, Pedro. O embate modernidade/pós-modernidade e seu impacto sobre a teoria e a prática educacionais. In: $E c c o S$, São Paulo, n. 28, p. 149-169. maio/ago. 2012. Disponível em: https://www.redalyc.org/pdf/715/71523339010.pdf. Acesso em: jan. 2021.

GUSDORF, Georges. Prefácio. In: JAPIASSU, Hilton. Interdisciplinaridade e patologia do saber. Rio de Janeiro: Imago Editora Ltda., 1976. p. 07-27.

HENRIQUE, Ana Lúcia Sarmento. Era uma vez... A história de um grupo em busca do reino perdido. In: HENRIQUE, Ana Lúcia Sarmento; SOUZA, Samir Cristino de (Orgs.). Transdisciplinaridade e complexidade: uma nova visão para a educação no século XXI. Natal: Editora do CEFET-RN, 2005.

JAPIASSU, Hilton. Interdisciplinaridade e patologia do saber. Rio de Janeiro: Imago Editora Ltda., 1976.

JAPIASSU, Hilton. Prefácio da primeira edição. In: FAZENDA, Ivani Catarina Arantes. Integração e interdisciplinaridade no ensino brasileiro. $6^{a}$ ed. São Paulo: EDIÇÕES 114 LOYOLA, 2011. p. 31-41.

KUHN, Thomas. A estrutura das revoluções científicas. Trad. Beatriz Vianna Boeira e Nelson Boeira. 6ª ed. São Paulo: Perspectiva, 2001.

REICHENBACH, Hans. Experience and prediction: An analysis of the foundation and the structure of knowledge. Chicago, Illinois: The University of Chicago Press, 1976.

SANTOS, Boaventura de Sousa. Um discurso sobre as ciências. $5^{\text {a }}$ ed. São Paulo: Cortez, 2008.

SOUSA, Juliane Gomes de; PINHO, Maria José de. Interdisciplinaridade e transdisciplinaridade como fundamentos na ação pedagógica: aproximações teóricoconceituais. In: Revista Signos, Lajeado, ano 38, n. 2, p. 93-110, 2017. Disponível em: http://univates.br/revistas/index.php/signos/article/view/1606. Acesso em: jan. 2021.

WATSON, James Dewey; CRICK, Francis Harry Compton. Molecular structure of Nucleic acids. In: Nature. April 25, vol. 171, 1953. 